ELORE (ISSN 1456-3010), vol. $16-1 / 2009$.

Julkaisija: Suomen Kansantietouden Tutkijain Seura ry.

[http://www.elore.fi/arkisto/1_09/kirjat_saarimaa_01_09.pdf]

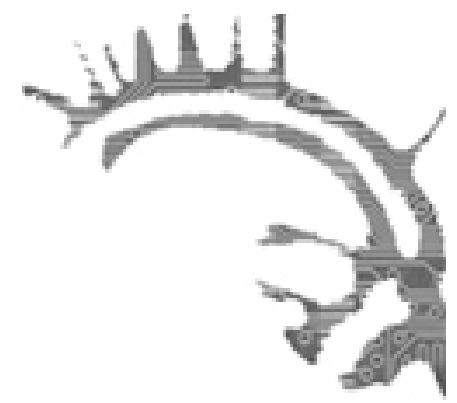

KIRJA-ARVIO:

\title{
Metsänhoitajuus Suomessa aikojen saAtossa
}

Paaskoski, Leena 2008: Herrana metsässä. Kansatieteellinen tutkimus metsänhoitajuudesta. Suomalaisen Kirjallisunden Seuran Toimituksia 1170. Helsinki: SKS. 320 sivua.

\section{$\underline{\text { Riikka Saarimaa }}$}

Humanistinen ja yhteiskuntatieteellinen metsätutkimus on viimeisen kymmenen vuoden aikana ilahduttavasti voimistunut Suomessa. Yksi esimerkki tällaisesta tutkimustoiminnasta on Metsäammatit metsätalouden murroksessa-muistitiedonkeruuhanke, jonka toteuttivat Metsähistorian Seura, Helsingin yliopiston kulttuurien tutkimuksen laitoksen kansatieteen oppiaine ja Suomen Metsämuseo Lusto vuosina 1999-2002 Metsämiesten Säätiön rahoittamana. Hankkeen aineisto koostuu yli tuhannen metsäammattilaisen elämäkertahaastatteluista, jotka on tallennettu Suomen Metsämuseo Luston arkistoon. Hankkeessa kartoitettiin kansatieteen näkökulmasta eri-ikäisten ja eri työnantajien palveluksessa olleiden metsäammattilaisten kuten metsätyöntekijöiden, metsureiden, kämppäemäntien, metsäkoneyrittäjien, metsäkoneenkuljettajien, metsätoimihenkilöiden ja metsänhoitajien työn ja arjen kokemuksia ja muuttumista erityisesti 1900-luvun jälkipuoliskon Suomessa.

\section{METSÄNHOITAJUUden LÄHTEILlä}

Leena Paaskosken väitöskirjatutkimuksen Herrana metsässä - Kansatieteellinen tutkimus metsänhoitajundesta tutkimuskohteena on metsäalan korkeimman koulutuksen saanut ammattiryhmä, metsänhoitajat. Teoksessa tarkastellaan metsänhoitajien ammattikulttuurista prosessia sadanneljänkymmenen vuoden aikana 1860-luvulta 2000-luvulle. Tutkimuksessa selvitetään metsänhoitajuuden rakentumista ja kehittymistä ammattisukupolvien yhteisenä kokemuksena. Tarkastelu kohdistuu metsänhoitajien omiin kokemuksiin ja muisteluihin elämästään metsänhoitajan ammatissa ja osana metsänhoitajakuntaa. Keskiössä on yksittäisten metsänhoitajien ja ammattikunnan yhteisten 


\section{MetsänhoitajuUs SUOMESSA AIKOJEN SAATOSSA}

ja yhteisöllisten kokemusten välinen suhde sekä suhteen vaikutus ammattikulttuurin rakentumiseen ja välittymiseen sukupolvelta toiselle.

Tutkimuksen pääasiallisena lähdeaineistona ovat edellä mainitussa muistitietohankkeessa tehdyt 226 metsänhoitajan elämäkerralliset haastattelut, metsänhoitajien yksityiset valokuvakokoelmat ja metsäylioppilaiden tekemät opiskelijalehdet. Näiden ohella aineistona on käytetty Hyytiälän metsäharjoitteluaseman seinäkirjoituksia, Luston museokokoelman esineistöä ja arkistoaineistoa, opiskelijayhdistysten ja Metsänhoitajaliiton pöytäkirjoja, Hyytiälä-päiväkirjoja, yksityiskirjeitä ja tutkijan omaa tutkimus- ja kenttätyöpäiväkirjaa. Tutkimusaineisto on varsin runsas ja monipuolinen, mikä asettaa tutkimukselle omat haasteensa. Moninaisen aineiston läpikäyminen, analyysi ja tulkinnallinen yhteen nitominen on tutkijan kannalta vaativaa. Erilaisiin aineistoihin pitää myös soveltaa eri tutkimusmenetelmiä, joten aineiston käsittely edellyttää pitkäjänteistä ja kärsivällistä perehtymistä. Tutkimusaiheen valinnan kannalta on kuitenkin ollut mielekäs ratkaisu laajentaa lähdeaineistoa jo sinänsä mittavaa haastatteluaineistoa laajemmalle. Niiden myötä tutkimuksessa sukelletaan syvemmälle metsänhoitajuuteen ja saadaan laajempi ymmärrys ammattikulttuurisesta prosessista ja yksilöiden kokemuksista osana prosessia. Myöskään kokonaiskuvaa metsänhoitajan ammatin koko kehityskaaresta ja metsänhoitajuudesta ei olisi pystytty tekemään pelkän haastatteluaineiston perusteella. Lisäksi on kiinnostavaa saada tietoa arkistojen kätköihin tallennetusta aineistosta, joka ei juuri ole ollut akateemisen tutkimuksen kohteena. Tutkimuksessa käytetyn muun kirjallisuuden myötä avautuvat näkökulmat tuovat aineistolähtöiseen ja kuvailevaan tutkimukseen virkeitä näkökulmia sekä aineiston jäsentelyyn ja tulkintaan sopivan viitekehyksen. Tällaista on esimerkiksi tutkimuksessa käytetty muistitietoon ja kulttuurianalyyttiseen tutkimukseen liittyvä tutkimuskirjallisuus.

Muistitietohankkeesta voisi tässä yhteydessä vielä mainita, että hankkeen aineistoa on hyödynnetty myös Katja Tervon (2008) väitöskirjassa Metsän biljaiset. Metsätyön rakennemurrosten kolme sukupolvea. Väitöskirjan arvio on ilmestynyt Katri Kauniston tekemänä Eloressa 2/2008.

\section{TUTKIMUKSEN KEHYSKERTOMUKSESTA METSÄNHOITAJUUDEN METATARINAAN}

Paaskoski tarkastelee metsänhoitajuutta alkaen vuodesta 1862, jolloin Suomessa alkoi metsänhoitajien koulutus Lammin pitäjässä Evon metsäopistossa. Varhaisiin vaiheisiin saakka haastatteluaineisto ei aivan yllä, mutta tutkija on käyttänyt muuta aineistoa alkuvaiheiden kartoittamisessa. Haastattelu- ja muu tutkimusaineisto käsittää ja käsittelee vahvemmin 1930-luvulta alkavaa ajanjaksoa aina 2000-luvulle asti.

Tutkimukseen johdattaa kehyskertomus, joka jäsentää ja auttaa hahmottamaan metsänhoitajien ammattikunnan syntyä, kehittymistä ja muutoksia. Kehyskertomuksessa tarkastellaan metsäalaa neljään osaan jaettuna ajanjaksona. Näiden periodien tarkoituksena on lähinnä auttaa metsänhoitajuuden historian ymmärrystä. 


\section{RIIKKA SAARIMAa}

Kehyskertomuksessa painottuvat sellaiset ammattikunnan historiaan kytkeytyvät asiat kuin metsänhoitajien koulutus, ammattikunnan koko, työllistyminen ja työnantajat sekä niissä tapahtuneet muutokset aikojen kuluessa. Paaskoski pitää periodijakoa tutkimuksessaan luonteeltaan teknisenä, koska aikakausien rajaaminen täsmällisiin vuosilukuihin ei ole tutkimuksessa kovinkaan olennaista. Tutkija myös myöntää, että hän ei ole tässä tutkimuksessa tuonut täsmällisesti esille kaikkia metsätalouden historian tavallisesti tärkeinä pidettyjä merkkipaaluja. Kansatieteellisen tutkimuksen kannalta on ollut tärkeämpää keskittyä asioihin, jotka taustoittavat parhaiten metsänhoitajien omia kertomuksia työstään ja elämästään. Metsähistorian tutkimus Suomessa on tuottanut aikaisemmin metsänhoidon, metsätutkimuksen ja -talouden historiaa valottavia tutkimuksia, joten on perusteltua jättää ne tämän tutkimuksen ulkopuolelle (ks. esim. Kuisma 1993; Kuisma 2008; Michelsen 1995; Tasanen 2004). Joka tapauksessa kehyskertomuksen periodit muodostavat tietynlaisen kronologisen kartan, johon metsänhoitajien omat kerrotut muistot ja kokemukset hyvin sijoittuvat. Kehyskertomus toimii hyvänä jäsentelyn apuna.

Kehyskertomuksen johdattamana tutkimuksessa siirrytään luvussa kolme tarkastelemaan metsänhoitajuuden rakentumista ammatinvalinnan, metsänhoitajien sukupolvien ketjun ja metsänhoitajien yhteisten opiskeluaikojen kokemusten välityksellä. Osiossa haastatteluaineiston analyysi ja tulkinta nousee tärkeäksi, mutta myös muun aineiston välityksellä pohditaan metsänhoitajuuden rakentumista ja niin sanotun metsämieshengen eli ammattiryhmän yhteishengen syntyjä. Luvussa neljä tarkasteluun tulee metsänhoitajien ammattikunnan jäsenyyttä vahvistavien ja ylläpitävien tekijöiden monitahoista analyysia. Tarkastelussa ovat muun muassa metsäylioppilaiden kurssiorganisaatio, metsäammattien hierarkiat, metsänhoitajien ulkoiset ryhmätunnukset, muistojen ja muistamisen tavat, metsänhoitajan työ, urakehityksen polut ja metsänhoitajan perheen arkitodellisuus. Tutkimus etenee luvussa viisi tarkastelemaan metsänhoitajuuden kuvaa monipuolistavasta näkökulmasta, kun tarkastellaan naispuolisten metsänhoitajien kokemuksia sekä tilannetta, jossa yliopistotasoinen metsäopetus Suomessa laajeni ja aloitettiin Helsingin yliopiston lisäksi vuonna 1982 Joensuussa. Luvussa tarkastellaan myös nuoremman polven, 1980-1990 luvulla opiskelleiden metsänhoitajien kokemuksia tilanteessa, jossa voimakkaasti muuttuva Suomen elinkeinorakenne, informaatioyhteiskunnan kehitys sekä moniarvoistuminen ja ympäristöarvojen korostuminen toivat uusia haasteita metsäalalle. Väitöskirjan kuvitus on huolella tehty ja näiden kuvien käyttäminen osana analyysia tuo tutkimukseen yhden merkittävän ulottuvuuden. Luvussa kuusi pohditaan vielä erikseen valokuvien, elokuvien ja kirjallisuuden tuottamia mielikuvia metsänhoitajuudesta. Viimeinen luku on tiivis yhteenvetoluku, jossa teorialähtöisesti luodaan metatarinaa metsänhoitajuudesta. 


\section{TutKImuksen MONET ULOTTUVUUdeT}

Tutkimusta metsänhoitajista on tehty Suomessa verrattain vähän, joten tämä perusteellinen tutkimus metsänhoitajien ammattikunnasta ja -kulttuurista täyttää mainiosti tuota puutetta. Tälle tutkimukselle ja koko muistitiedonkeruuhankkeelle on ollut valtava tarve. Yksittäisten metsäalalla toimineiden henkilöiden muistiinpanoja, muistelmia, historiikkeja ja metsäalaan liittyvää muuta arkistoaineistoa on olemassa, mutta sen tutkiminen ja tulkinta olisi huomattavasti yksipuolisempaa ilman tätä haastattelujen tuottamaa rikasta aineistoa.

Työ on kansatieteen väitöskirja ja nivoutuu siinä yhteydessä kansatieteellisen ammattikuntatutkimuksen perinteeseen, mutta se sivuaa myös yhteiskunnallisempaa asiantuntijuustutkimusta. Tutkimus on jatkumoa myös kansatieteelliselle metsätutkimukselle, kuten Hanna Snellmanin väitöskirjalle (1996). Tutkimuksessa piirtyy myös yksittäisten metsänhoitajien ja yhden ammattiryhmän kokemusten kautta kuva suomalaisen yhteiskunnan muutoksesta metsätalouteen perustuvasta elinkeinorakenteesta kohti informaatioyhteiskuntaa. Metsänhoitajuuden tarkastelu kuvastaa kulttuurin muuntuvuutta. Tämän tutkimuksen myötä kulttuurin muutosdynamiikka tulee kouriintuntuvasti esille myös metsäalan näkökulmasta. Omalla tavallaan kulttuurin muutos on surullista, kun prosessissa jotakin vanhaa kuolee pois uuden tieltä, mutta tieto entisestä jää kuitenkin elämään tutkimuksissa.

Tällä tutkimuksella on tärkeä sija humanistisessa ja kulttuurintutkimuksellisessa metsätutkimuksessa, mutta tutkimusta voidaan lukea myös osana laajempaa yhteiskunnallista metsä- ja ympäristökeskustelua.

\section{KirjallisuUs}

KAUNISTO, KATRI 2008: Metsäammattilaisten sukupolvet. Kirja-arvio. Elore, Vol. 15 - 2/2008. [http://www.elore.fi/arkisto/2_08/kau2_08.pdf].

KUISMA, MARKKU 1993: Metsäteollisunden maa. Suomi, metsät ja kansainvälinen järjestelmä 1620-1920. Helsinki: Suomen Historiallinen Seura.

KUISMA, MARKKU (toim.) 2008: Kriisi ja kumous. Metsäteollisuus ja maailmantalouden murros 1973-2008. Metsäteollisuuden maa 5. Helsinki: SKS.

MICHELSEN, KARL-ERIK 1995: History of Forest Research in Finland. Part 1. The Unknown Forest. Helsinki: The Finnish Forest Research Institute.

SNELLMAN, HANNA 1996: Tukkilaisen tulo ja lähtö. Kansatieteellinen tutkimus Kemijoen metsä- ja uittotyöstä. Oulu: Pohjoinen.

TASANEN, TAPANI 2004: Läksi punt ylenemähän. Metsien hoidon historia Suomessa keskiajalta metsäteollisunden läpimurtoon 1870-luvulla. Helsinki: Metsäntutkimuslaitos.

TERVO, KATJA 2008: Metsän hiljaiset. Metsätyön rakennemurrosten kolme sukupolvea. Helsinki: SKS.

Filosofian maisteri Riikka Saarimaa toimii tutkijana Turun kauppakorkeakoulun Tulevaisuuden tutkimuskeskuksessa. 